\title{
An Oxygen isotope record of lacustrine opal from a European Maar indicates climatic stability during the last interglacial
}

\author{
Aldo Shemesh $^{1}$, Miri Rietti-Shati ${ }^{1}$, Patrick Rioual ${ }^{2}$, Rick Battarbee ${ }^{2}$, \\ Jacques-Louis de Beaulieu ${ }^{3}$, Maurice Reille ${ }^{3}$, Valerie Andrieu ${ }^{3}$ and \\ Helena Svobodova ${ }^{4}$
}

\begin{abstract}
The penultimate temperate period, 127 - 110 ka before present (BP), bracketed by abrupt shifts of the global climate system initiating and terminating it, is considered as an analogue of the Holocene because of a similar low global ice-volume. Ice core records as well as continental and marine records exhibit conflicting evidence concerning the climate variability within this period, the Last Interglacial. We present, for the first time, a high-resolution record of oxygen isotopes in diatom opal of the Last Interglacial obtained from the Ribains Maar in France (44 50'09"N 3 $3^{\circ} 49^{\prime} 16^{\prime \prime} \mathrm{E}$ ). Our results indicate that the Last Interglacial in southwestern Europe was generally a period of climatic stability. The record shows that the temperate period was initiated by an abrupt warm event followed midway by a minor climatic transition to a colder climate. An abrupt isotopic depletion that occurs simultaneously with abrupt changes in pollen and diatom assemblages marks the end of the temperate period, and is correlative with the Melisey I stadial. Variations in the isotopic composition of lake-water related to the isotopic composition of precipitation and evaporation dominate the biogenic opal oxygen isotope record.
\end{abstract}

\section{Introduction}

The great variability of glacial climate is a well-established fact [Dansgaard et al., 1993], but the climatic variability of interglacial periods, especially of the last one, is still under debate [McManus et al., 1994; Kukla et al., 1997; Adams et al., 1999; Kukla, 2000]. It has been pointed out that the Holocene climate stability is a coincidental anomaly that enabled human civilizations to flourish due to the conditions favorable for the development of agriculture [Dansgaard et al., 1993]. On the other hand, data from marine cores suggest that the stability was typical of previous interglacials as well [McManus et al., 1999]. This study addresses the continental climatic stability of the Last Interglacial, the last Pleistocene period presumed to have had a climate similar to that of the present interglacial, the Holocene.

\footnotetext{
${ }^{1}$ Department of Environmental Sciences and Energy Research, Weizmann Institute of Science, 76100 Rehovot, Israel.

${ }^{2}$ Environmental Change Research Centre, University College London, 26 Bedford Way, London WC1HOAP, UK.

${ }^{3}$ Laboratoire de Botanique Historique et Palynologie, UDESAM, ESA CNRS 6116, Faculte' des Sciences et Techniques Saint Jrme, 13397 Marseille Cedex 20, France

${ }^{4}$ Botanical Institute, CZ25243, Czech Republic
}

Copyright 2001 by the American Geophysical Union.

Paper number 2000GL012720.

0094-8276/01/2000GL012720\$05.00
Continental paleoclimate records [Frogley et al., 1999; Frumkin et al., 1999] complement marine [Cortijo et al., 1994; Adkins et al., 1999] and polar ice-cores [Petit et al., 1999] of the climatic variability of the Last Interglacial. In the Massif Central, at the Lac du Bouchet sediment sequence, an intra-interglacial cooling has been suggested [Thouveny et al., 1994]. However, this cooling has not been confirmed by the pollen based quantitative climate reconstruction [Cheddadi et al., 1998]. In the Ribains Maar (Figure 1A), situated $8 \mathrm{~km}$ away from Lac du Bouchet, a thick diatomitic sequence accumulated during the Last Interglacial and the early Glacial [Beaulieu and Reille, 1992], provides an opportunity to develop a complementary and independent climate reconstruction from oxygen-isotope of biogenic opal.

Oxygen-isotope data from lacustrine authigenic precipitates formed in isotopic equilibrium with lake waters such as carbonates [Stuiver, 1970; McKenzie et al., 1993; Frogley et al., 1999] and biogenic opal [Shemesh and Peteet, 1998; Rietti-Shati et al., 1998; Rosqvist et al., 1999] provide reconstruction of climatic fluctuations independent of possible anthropogenic influence. In lacustrine studies the authigenic origin of diatom silica is an important advantage in comparison to carbonates [Drescher-Schneider, 1998; Litt et al., 1996]. Diatom $\delta^{18} O, \delta^{18} O_{s i}$, depends on the isotopic compo-

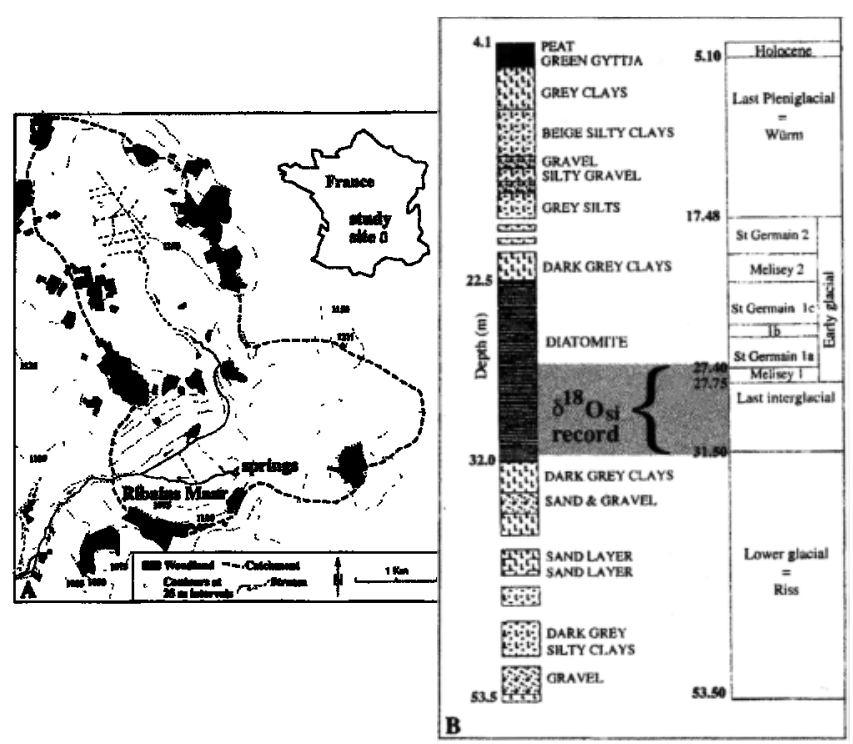

Figure 1. Location map of the Ribains Maar (A) and the Ribains maar $53.5 \mathrm{~m}$ sediment core pollen stratigraphy and chronology (B; [Beaulieu and Reille, 1992]). The gray area marks the sequence analyzed for $\delta^{18} O_{s i}$. 


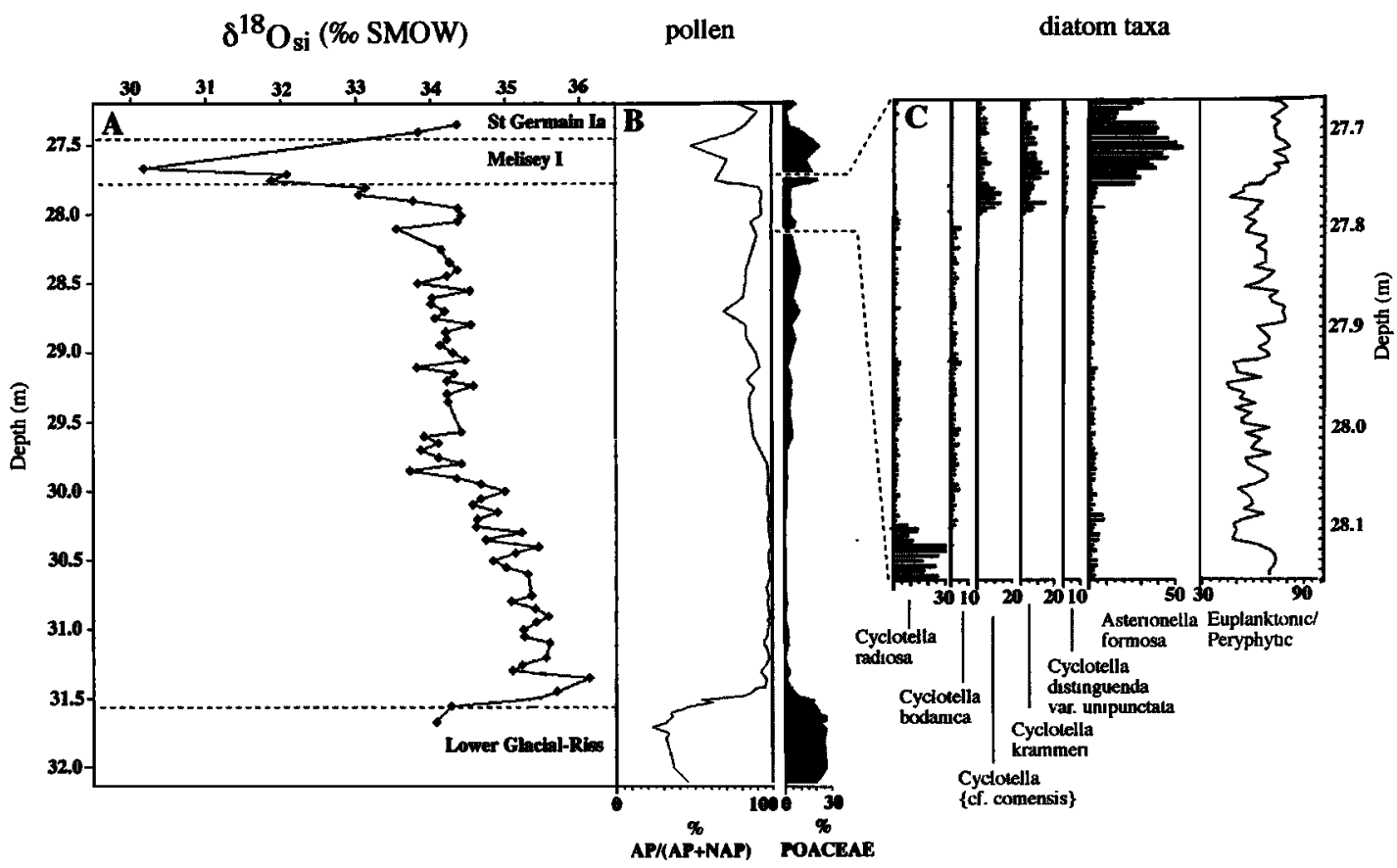

Figure 2. A. The oxygen isotope ratio record of biogenic opal $\left(\delta^{18} O_{s i}\right)$ obtained from the Ribains sequence of the Last Interglacial, Melisey I stadial and initiation of St Germain Ia interstadial; B the arboreal vs. non-arboreal (AP/(NAP+AP)) and Poaceae pollen counts of the Last Interglacial section, Melisey I stadial and part of St Germain Ia interstadial; $\mathbf{C}$ diatom counts of the termination of the Last Interglacial and initiation of the Melisey I stadial.

sition of the water $\left(\delta^{18} O_{w}\right)$ from which it was secreted and on ambient temperature $\left(-0.5^{\circ} / 00{ }^{\circ} \mathrm{C}^{-1}\right)$ [Juillet-Leclerc and Labeyrie, 1987; Shemesh et al., 1992] and has been shown to retain its isotopic signal in the ocean on timescales of at least $430 \mathrm{ka}$ [Shemesh et al., 1995]. The $\left(\delta^{18} O_{w}\right.$ of a lake depends on the $\left(\delta^{18} O_{w}\right.$ of the influx, the hydrological setting (mainly the precipitation to evaporation ratio, $\mathrm{P} / \mathrm{E}$ ) and the local climate. Changes in the $\delta^{18} \mathrm{O}$ of the local precipitation replenishing a lake occur due to variations of ambient surface temperatures or modifications in atmospheric circulation. Such modifications may either shift the moisture-source area or change the vapor transport efficiency. The present dependence of $\delta^{18} \mathrm{O}$ on precipitation at mid-latitudes on surface temperatures is $0.58^{\circ} / 00{ }^{\circ} \mathrm{C}^{-1}$ [Rozanski et al., 1993]. A similar slope was suggested in Europe for the Last Glacial (35-30 ka BP [Rozanski, 1985; Beyerle et al., 1998]) but for older periods the slope is unknown.

\section{Methods}

\section{Analytical}

In 1988, a 54-m core was taken at the Ribains Maar (Figure 1A) situated $1080 \mathrm{~m}$ above sea level. The Ribains paleolake has probably been fed by groundwater seepage from an intra-basaltic aquifer [Rioual et al., 1998]. On the basis of the pollen study a chronology was proposed for the lithostratigraphical unit [Beaulieu and Reille, 1992] spanning from about $230 \mathrm{ka} \mathrm{BP}$ [Petit et al., 1999] to present. It was the first high-altitude paleolake in France in which evidence of the Last Interglacial was found [Beaulieu and Reille, 1992]. Between 32 and $22.5 \mathrm{~m}$ depth, a diatomite sequence rich in organic matter suggests an undisturbed and homogeneous infilling during the Last Interglacial and Early
Glacial (Figure 1B). This diatomite sequence was studied at high resolution for $\delta^{18} O_{s i}$, pollen and diatom assemblages.

71 diatom samples were obtained from the interval 31.67 to 27.35 meters at a resolution of $5 \mathrm{~cm}$. The gap of 20 $\mathrm{cm}$ (between 28.35 and $28.15 \mathrm{~m}$ ) is the result of the coring technique and does not represent a discontinuity is the sequence. The samples were physically cleaned by sieving and differential settling in sodium polytungstate solutions to extract pure diatom frustules from the sediment. The frustules in the size fraction $<20 \mu \mathrm{m}$ were treated with a mixture of concentrated $\mathrm{HNO}_{3} / \mathrm{HClO}_{4}$ to remove organic matter [Shemesh et al., 1995]. Then the samples underwent partial isotopic exchange under controlled conditions [Juillet Leclerc and Labeyrie, 1987], were recrystallized and subsequently fluorinated to extract the oxygen. The oxygen was converted to $\mathrm{CO}_{2}$ which was then analyzed for its isotopic composition by an upgraded MAT-250 mass-spectrometer. The results were calibrated versus NBS-28 quartz international standard and are reported in the $\delta$ notation relative to V-SMOW. The long-term reproducibility is $0.14^{\circ} / 00$.

Diatom and pollen counts were performed at a higher resolution as described in Rioual [1998] and Reille et al. [2000], respectively.

\section{Stratigraphy}

In Europe, four French sites present rare continuous sedimentary records from the present to at least the penultimate Glacial. This continuity, showing a succession of welldefined and correlative pollen zones, allows an unequivocal identification of the Last Interglacial interval [Cheddadi et al., 1998]. In the pollen sequences, the expansion and regression of forest taxa, respectively, mark the initiation and termination of interglacials. Due to the lack of absolute 
dating, the age and duration of the Last Interglacial are estimated on the basis of correlation with the marine isotope stages (MIS) in the deep-sea cores. Here we follow the recent correlation that the Melisey I stadial, the cold event that followed the Last Interglacial, corresponds to the C24 cold event in the North Atlantic cores, dated $106 \mathrm{ka}$ BP [Kukla et al., 1997; Sanchez-Goni et al., 1999]. Thus it appears that the Continental Last Interglacial corresponds to the entire MIS 5e and to the lower part of MIS 5d, 137 to 110 ka BP. In the local pollen Biozones [Reille et al., 2000] terminology our Lower glacial (Riss) corresponds to "Costaros glacial", the Last Interglacial corresponds to "Ribains interglacial", Melisey I corresponds to "St. Nicolas Stadial" and St Germain 1 corresponds to "St Geneys 1".

\section{Results and Discussion}

In southeast Europe high relative abundance of Poaceae and the low ratios of arboreal to non-arboreal pollen (AP/ (NAP+AP); Figure $2 \mathrm{~B}$ ) characterize the vegetation of cold periods. Our data show an abrupt decrease in Poaceae counts and a sharp increase in the $\mathrm{AP} /(\mathrm{NAP}+\mathrm{AP})$ at about $31.50 \mathrm{~m}$, marking the transition between the Lower Glacial (Riss stage) and the Last Interglacial. The same pollen pattern is observed in two other levels. The first and the most pronounced is at $27.75 \mathrm{~m}$ and corresponds to the onset of the Melisey I stadial. The second is indicated by a slight increase in counts in the middle of the Interglacial, at 29.90 m.

Diatom species counts were performed at the highest resolution $(5 \mathrm{~mm}$ ) between 28.15 and $27.67 \mathrm{~m}$. (Figure 2C). The rise in the diatom species Asterionella Formosa at $27.75 \mathrm{~m}$ is simultaneous with the abrupt increase in Poaceae counts and the abrupt decrease in AP/(NAP+AP). Between 27.75 and $27.65 \mathrm{~m}$ the euplanktonic to periphytic diatoms ratio is constant and Cyclotella species are abundant.

NAP counts in another French sediment sequence, La Grande Pile core, are anti-correlated [Kukla et al., 1997] with variations of sea-surface temperature (SST) in the eastern North Atlantic [McManus et al., 1994]. Similarly, in the Ribains sequence the decrease in Poaceae and increase in $\mathrm{AP} /(\mathrm{NAP}+\mathrm{AP})$ at 31.50 and $27.4 \mathrm{~m}$ mark the initiation of the temperate periods, i.e., the Last Interglacial and the St Germain Ia interstadial. The line of demarcation between the Last Interglacial and the Melisey I stadial is at 27.75 $\mathrm{m}$, where it Poaceae counts increase and AP/(NAP+AP) drops. The simultaneous abrupt rise in Asterionella Formosa, a species favored by late spring overturn [Maberly et al., 1994] resulting from a longer period of ice-cover, indicates the establishment of a considerably colder climate. The constant euplanktonic to peryphytic diatoms ratio and the abundance of Cyclotella, a species that is present in a lake only when lake-level is sufficiently high to allow for summer stratification to take place, indicate that no major changes in lake level [Wolin and Duthie, 1999] occurred during this abrupt climatic transition.

The $\delta^{18} O_{s i}$ curve covers the depth interval of 31.7 to $27.35 \mathrm{~m}$ (Figure 2A). At the termination of the Riss Glacial, $31.7-31.55 \mathrm{~m}$, the curve has a value of $34^{\circ} \%$. Consequently, within $15 \mathrm{~cm}$ the $\delta^{18} O_{s \imath}$ becomes abruptly enriched by $2 \%$, after which the value drops again to $35^{\circ} \%$ at 31.3 $\mathrm{m}$. Thereupon, up to $30.0 \mathrm{~m}$ the record has a low variability with an average $\delta^{18} O_{s i}$ of $35.2 \pm 0.4^{\circ} / 00$. At the end of this stable stage occurs a $1^{\circ} / 00$ shift to a second stable stage, characterized by an average of $34.3 \pm 0.3^{\circ} \%$, which persists until $27.95 \mathrm{~m}$. This second stable part of the record is terminated by an abrupt isotopic shift to a value of $30.2^{\circ} / 0$ within $30 \mathrm{~cm}$ at the Melisey I stadial. The two uppermost $\delta^{18} \mathrm{O}_{s_{2}}$ samples at the onset of the St Germain I interstadial, $27.4-27.35 \mathrm{~m}$, have enriched $\delta^{18} O_{s i}$ values of about $34^{\circ} / 00$, similar to the values of the younger stable period of the Last Interglacial $(30.0-27.95 \mathrm{~m})$. The transition from the temperate climate of the Last Interglacial to the Melisey I stadial occurred within 900 - 1900 years, following the hypotheses that the Last Interglacial lasted 11 or $23 \mathrm{ka}$ on the continents [Frogley et al., 1999; Sanchez-Goni et al., 1999; Kukla et al., 1997] and assuming a constant sedimentation rate in the lake. The Ribains $\delta^{18} O_{s \imath}$ curve has a similar figuration as the planktonic oxygen isotopic curve of the Last Interglacial from a marine core MD95-2042 in the southwestern margin of the Iberian Peninsula [Sanchez-Goni et al., 1999], but we note that on the $\delta^{18} O$ scale the trends of change are anti-correlated.

The diatom $\delta^{18} O_{s 2} \mathrm{i}$ record shows that overall the Last Interglacial in southwestern Europe was a period of climatic stability. It begins with a $2 \%$ enrichment at the RissInterglacial boundary and within the temperate period, two climatic regimes are evident, dividing the Last Interglacial into two phases almost equal in duration. The first is the $\delta^{18} O_{s i}$ enriched phase at the initiation of the Last Interglacial and the second is $1 \%$ depleted. The $2 \%$ oo enrichment at the base of the Ribains $\delta^{18} O_{s i}$ record may be explained by a regional warming that caused a decrease in $\mathrm{P} / \mathrm{E}$ of the lake and/or that enriched the local precipitation $\delta^{18} O$. A short warm event at the initiation of the Last Interglacial appears in two other European pollen records, Saint Front and Le Bouchet [Cheddadi et al., 1998] and is consistent with the $\delta^{18} O_{s i}$ enrichment. This implies that the combined effect of $\mathrm{P} / \mathrm{E}$ and precipitation change overwhelm the temperature dependency of the biogenic silica. This warm event is followed by a relatively long period of stable climatic conditions. The mid-Interglacial 1 depletion in $\delta^{18} O_{s 2}$ at about $30 \mathrm{~m}$ is in accordance with the establishment of a moderately colder climate indicated by the contemporaneous decrease in the $\mathrm{AP} /(\mathrm{NAP}+\mathrm{AP})$ ratio and increase in Poaceae (Figure 2B). It is also in agreement with the colder and dryer climate suggested by pollen records in continental and marine sites [Sanchez-Goni et al., 1999].

The $4^{\circ} / 0$ depletion in the Ribains $\delta^{18} O_{s i}$ record during Melisey I event can be caused by a substantial increase in the $\mathrm{P} / \mathrm{E}$ ratio or a large depletion in the $\delta^{18} \mathrm{O}$ of groundwater through the cooling effect on precipitation. The diatom assemblages during Melisey I suggest constant lake level and extended periods of ice cover, which can reduce evaporation and generate high $\mathrm{P} / \mathrm{E}$ ratios for this period. The Ribains $4^{\circ} / 0$ depletion is also simultaneous with an abrupt drop in North Atlantic SST [Sanchez-Goni et al., 1999]. An increase in the temperature difference between the moisture source and the site leads to a decrease in the proportion of the original moisture arriving and consequently reduces the $\delta^{18} \mathrm{O}$ of precipitation.

The comparison of our record to other studies indicating climatic stability during the Last Interglacial [McManus et al., 1994] depends on whether the period termed the Last Interglacial in these studies covers the same time interval as our study. It is possible that only the older stage of the 
temperate period in the Ribains record corresponds to the minimum ice-volume period MIS $5 \mathrm{e}$ and to the elapsed part of the Holocene [Kukla, 2000]. If this is correct, climate in Europe was warm and stable during the first 10-12 ka of the Last Interglacial, and somewhat colder but still stable during the $10 \mathrm{ka}$ that followed. This implies that the next shift of the global climate system might be towards a somewhat colder but still stable climate, rather than a shift towards a full Glacial. In order to explore the likelihood of such a scenario it is necessary to establish better the chronology of the continental Last Interglacial and its relation to MIS 5.

Acknowledgments. This publication was supported by the Israel Science Foundation and by the British Natural Environmental Research Council.

\section{References}

Adams, J., M. Maslin, and E. Thomas, Sudden climate transitions during the Quaternary. Progress in Physical Geography, 23(1), $1-36,1999$.

Adkins, J.F., et al., Variability of the North Atlantic thermohaline circulation during the last interglacial period. Nature, 390, 154-156, 1997.

Beaulieu, J.L.d. and M. Reille, Long Pleistocene pollen sequences from the Velay Plateau (Massif Central, France). Veget. Hist. Archaeobot., 1, 233-242, 1992.

Beyerle, U., et al., Climate and groundwater recharge during the last glaciation in an ice-covered region. Science, 282, 731-734, 1998.

Cheddadi, R., et al., Was the climate of the Eemian stable? A quantitative climate reconstruction from seven European pollen records. Palaeogeography Palaeoclimatology Palaeoecology, 149, 73-85, 1998.

Cortijo, E., et al., Eemian cooling in the Norwegian Sea and North Atlantic ocean preceding continental ice-sheet growth. Nature, 372, 446-449, 1994.

Dansgaard, W., et al., Evidence for general instability of past climate from a 250-kyr ice-core record. Nature, 364, 218-220, 1993.

Drescher-Schneider, R. and W. Papesch, A contribution towards the reconstruction of Eemian vegetation and climate in central Europe: first results of pollen and oxygen-isotope investigations from Mondsee, Austria. Vegetation History and Archaeobotany, 7(4), 235-240, 1998.

Frogley, M.R., P.C. Tzedakis, and T.H.E. Heaton, Climate variability in northwest Greece during the last interglacial. Science, 285, 1886-1889, 1999.

Frumkin, A., D.C. Ford, and H.P. Schwarcz, Continental oxygen isotopic record of the last 170,000 years in Jerusalem. Quaternary Research, 51, 317-327, 1999.

Juillet-Leclerc, A. and L. Labeyrie, Temperature dependence of the oxygen isotopic fractionation between diatom silica and water. Earth and Planetary Science Letters, 84, 69-74, 1987.

Kukla, G., et al., How long and how stable was the last interglacial? Quaternary Science Reviews, 16, 605-612, 1997.

Kukla, G., The Last Interglacial. Science, 287, 987-988, 2000.

Litt, T., F.W. Junge, and T. Bottger, Climate during the Eemian in north-central Europe - A critical review of the palaeobotanical and stable isotope data from central Germany. Vegetation History and Archaeobotany, 5, 247-256, 1996.

Maberly, S.C., et al., The Rise and Fall of Asterionella-Formosa in the South Basin of Windermere - Analysis of a 45-Year Series of Data. Freshwater Biology, 31, 19-34, 1994.

McKenzie, J.A. and D. Hollander, Oxygen isotope record in recent carbonate sediments from lake Greifen, Switzerland (17501986): application of continental isotopic indicator for evaluation of changes in climate and atmospheric circulation patterns, in Climate Change in Continental Isotopic Records, P.K. Swart, et al., Editors. American Geophysical Union: Washington, USA. pp. 101-111, 1993.
McManus, J.F., et al., High-resolution climate records from the North Atlantic during the last interglacial. Nature, 371, 326329, 1994.

McManus, J.F., D.W. Oppo, and J.L. Cullen, A 0.5-million-year record of millennial-scale climate variability in the North Atlantic. Science, 283, 971-975, 1999.

Petit, J.R., et al., Climate and atmospheric history of the past 420,000 years from the Vostok ice core, Antarctica. Nature, $399,429-436,1999$.

Reille, M., Beaulieu J.-L. de, Svobodova, H., Andrieu-Ponel, V., and C. Goeury, Pollen biostratigraphy of the last five climatic cycles from a long continental sequence from the Velay region (Massif Central, France). J. Quaternary Science, 15(7), 665$685,2000$.

Rietti-Shati, M., A. Shemesh, and W. Karlen, A 3000-year climatic record from biogenic silica oxygen isotopes in an equatorial high-altitude lake. Science, 281, 980-982, 1998.

Rioual, P., et al., Palaeoecological study of the lacustrine sediment of Ribains maar (Haute-Loire, Massif Central, France) during the transition between the last interglacial and the last glacial periods. Archiv Fur Hydrobiologie, 142, 317-341, 1998.

Rosqvist, G.C., M. Rietti-Shati, and A. Shemesh, Late glacial to middle Holocene climatic record of lacustrine biogenic silica oxygen isotopes from a Southern Ocean island. Geology, 27, 967-970, 1999.

Rozanski, K., Deuterium and oxygen-18 in European Groundwaters-links to atmospheric circulation in the past. Chemical Geology (Isotope Geoscience Section), 52, 349-363, 1985.

Rozanski, K., L. Araguas-Araguas, and R. Gonfiantini, Isotopic patterns in modern global precipitation, in Climate Change in Continental Isotopic Records, P.K. Swart, et al., Editors. American Geophysical Union: Washington, 1-36, 1993.

Sanchez-Goni, M., et al., High resolution palynological record off the Iberian margin: direct land-sea correlation for the Last Interglacial complex. Earth and Planetary Science Letters, 171, 123-137, 1999.

Shemesh, A., C.D. Charles, and R.G. Fairbanks, Oxygen isotopes in biogenic silica: global changes in ocean temperature and isotopic composition. Science, 256, 1434-1436, 1992.

Shemesh, A. and D. Peteet, Oxygen isotopes in fresh water biogenic opal - Northeastern US Allerod-Younger Dryas temperature shift. Geophysical Research Letters, 25, 1935-1938, 1998.

Stuiver, M., Oxygen and carbon isotope ratios of fresh-water carbonates as climatic indicators. Journal of Geophysical Research, 75, 5247-5257, 1970.

Thouveny, N., et al., Climate variations in Europe over the past $140 \mathrm{kyr}$ deduced from rock magnetism. Nature, 371, 503-506, 1994.

Wolin, J. and H. Duthie, Diatoms as indicators of water level change in freshwater lakes, in The diatoms: applications for the Environmental and Earth sciences, E. Stoermer and J. Smol, Editors. Press Syndicate of the University of Cambridge: Cambridge, pp. 183-204, 1999.

Aldo Shemesh and Miri Rietti-Shati, Department of Environmental Sciences and Energy Research, Weizmann Institute of Science, 76100 Rehovot, ISRAEL. (e-mail: Aldo.Shemesh@ weizmann.ac.il),

Patrick Rioual and Rick Battarbee, Environmental Change Research Centre, University College London, 26 Bedford Way, London WC1HOAP, UK.

Jacques-Louis de Beaulieu, Maurice Reille and Valerie Andrieu, Laboratoire de Botanique Historique et Palynologie, UDESAM, ESA CNRS 6116, Faculte' des Sciences et Techniques Saint Jrme, 13397 Marseille Cedex 20, FRANCE

(Received December 4, 2000; revised March 13, 2001; accepted March 15, 2001.) 